Journal of Finance and Accounting

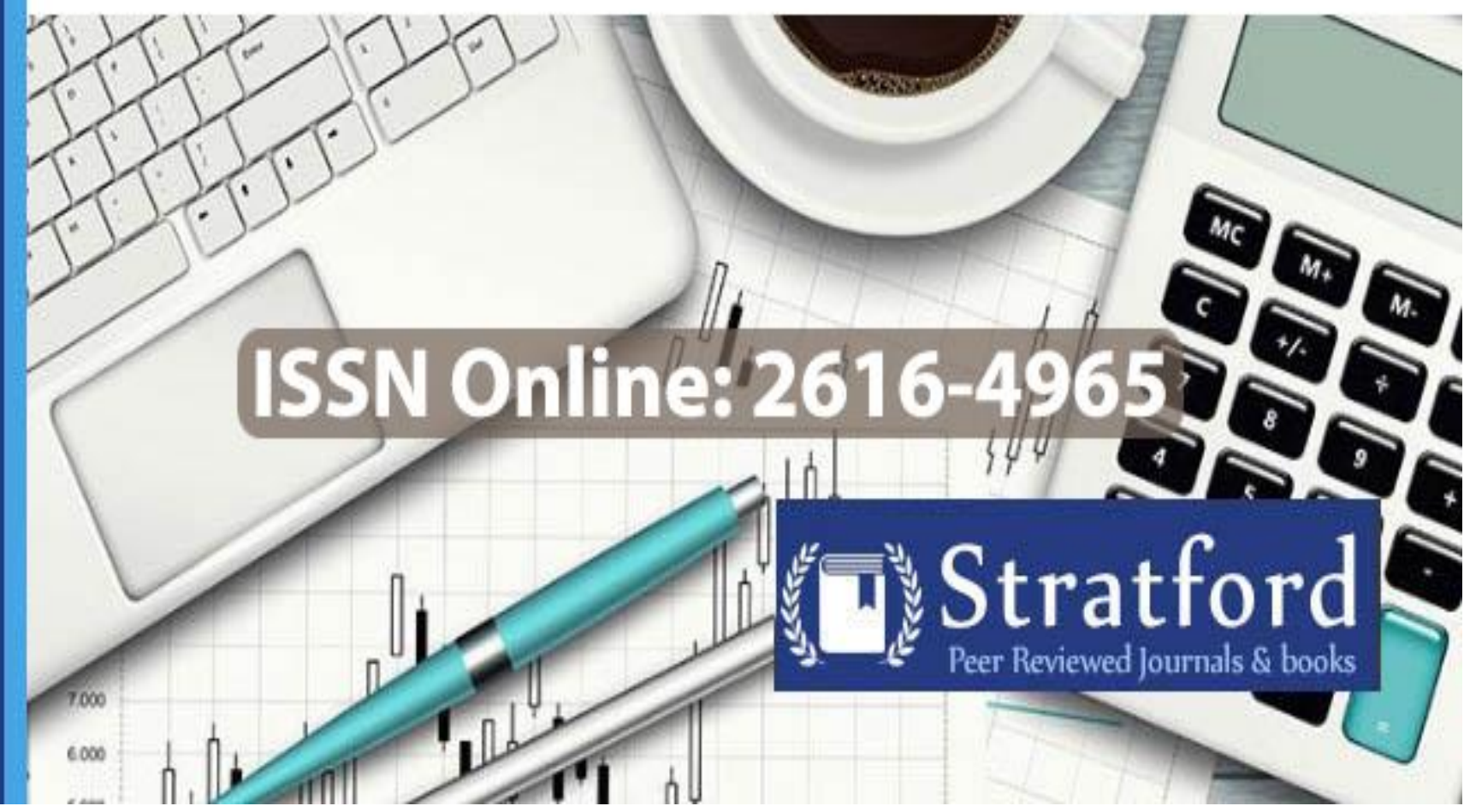

Consequences of Misallocation of Financial Resources on Cost Management: Evidence from Global Markets

Yang Wu \& Chuan Vuong

ISSN: 2616-4965 


\title{
Consequences of Misallocation of Financial Resources on Cost Management: Evidence from Global Markets
}

\author{
Yang Wu, Tsinghua University \\ Chuan Vuong, Tsinghua University
}

How to cite this article: Wu Y. \& Vuong C. (2021). A Review of the Cybersecurity Programs in the United States Army. Journal of Finance and Accounting. Vol 5(4) pp. 1-11. https://doi.org/10.53819/81018102t2018

\begin{abstract}
Due to competitiveness in the global marker, firms must be strategic in order to survive. Therefore, setbacks arising from financial misallocation need to addressed by implementing systems that give the firm a competitive advantage and protects the firm position within the industry it operates. There is a need to transition from traditional methods of accounting to modern methods to ensure that financial misallocations are a thing of the past. By doing so, the firm will move from being reactive to being proactive as well as have access to accurate information that will facilitate strategizing and decision making. Financial misallocations have, therefore led to the demand for more sophisticated accounting techniques and methods. This has, in turn, made cost management a managerial process instead of an accounting activity. Furthermore, these systems have changed the role of the management accountant from reporting to a more involved stakeholder in strategy and decision making. This has led to the loss of various skills and competencies among accountants since some of their functions are now computerized. There is, however, a lot of apprehension in adopting these new sophisticated techniques of accounting, a subject that should perhaps be investigated further.
\end{abstract}

Keywords: Financial Resources, Cost Management \& Global Markets.

\subsection{Introduction}

Cost management is a branch of management accounting dedicated to ensuring businesses adhere to the budget to optimize revenue. Cost management, therefore, helps management to make informed decisions during financial planning and determining the best long term strategy for an organization. It acts as a form of control of actual or predicted costs that are incurred by a business. 
One of the most important functions of internal accounting information is to facilitate the development and execution of business strategies (Restuccia \& Rogerson, 2017).

Business management revolves around four major processes: The formulation of strategies; The communication of these strategies throughout the organization; Development of tactics to implement the business strategy; Development and administration of controls to gauge the success of the implementation process (Spraakman, O'Grady, Askarany \& Akroyd, 2018). In all these processes, accurate cost information plays a crucial role. Strategic cost management is, therefore intertwined with the strategic management cycle; the goal of the accountant is to, therefore, provide cost management information that aids towards the implementation of an organization's strategy. Cost management information comprises of both financial and non-financial information. There is financial information regarding cost and revenues and non-financial information about customer satisfaction, quality, productivity among other vital success factors for an organization (Restuccia, \& Rogerson, 2017). With the escalating pressures from economic recessions, technological innovations, competition in the global market, and businesses processes changes, cost management has become more essential to the success of a business. As a result, cost management practices have become more responsive to changes in business conditions. This is because managers are required to think competitively, and thus become more strategic. Strategic thinking is forwardlooking and therefore involves anticipating changes and being in a position to accommodate these changes (Lenzu \& Manaresi, 2019).

Leaders of an organization are accountable for how the financial resources of an organization are used (Hao, Gai \& Wu, 2020). After misallocation, these leaders are often forced to reevaluate and come up with better systems of tracking how the money is used. This requires the employment of more sophisticated accounting systems and methods that will help management make better decisions, especially pertaining to how financial resources will be assigned. Furthermore, budgeting for the use of particular resources during specific accounting periods is an indispensable component of the management and planning process (Wang, Lei, Yang \& Zhao, 2021). This process, combined with cost accounting methods facilitate decision making since it is possible to predict costs and returns of various ventures. Budgeting and cost management procedures, therefore, enable management to choose the most feasible option among available business opportunities (Drucker, 2012). This is necessary because resources to be committed to various ventures are always limited. The budget, therefore, becomes a manager's tool to limit expenditure and help deal with the challenge of aligning resources in a manner which help achieve organizational goals (Nguyen \& Nguyen, 2020).

Organizations are also in the pursuit of improved efficiency; as such, there is a feedback mechanism in place which allows for cost estimates or ratios to be tracked over time (Marconi, D., \& Upper, 2017). With this information, it is possible to determine what methods or approaches are most efficient; this then allows for processes to be improved, which in turn leads to increased efficiency. The ideal goal of any organization is to be both efficient and cost-effective. This, therefore, means that the benefits of any initiative should be greater than the costs involved. Managers are, thus presented with the challenge of developing and implementing policies that decrease or limit waste (Drucker, 2012). 
Every decision a business makes has financial implications and as such managers must make investment decisions that give the best returns, choose the right combination of debt and equity and decide on the optimal amount of money to be returned to owners and what is to be kept in the business as a cash balance. Every business, whether large or small, private or public has to make investment, financing, and dividend decisions. These decisions are made with the general objective of maximizing value (Boeri, Ichino, Moretti \& Posch, 2019).

\subsection{Current situation}

The need for accurate financial information cannot be overemphasized in any industry; this is because many strategic decisions are made based on available financial information. The accuracy of financial information is dependent on the accounting methods and practices in place. As such, there is a need for more sophisticated systems that analyze and predict data since these modern methods are more accurate. Developments in technology have expanded the amount of information that is available to the manager and as such technology has become a critical part of the cost management process (Hopper \& Bui, 2016). Currently, there is a variety of management accounting methods and procedures; these tools and cost analytic methodologies support decisions by managers.

A study conducted by Acabbi, Panetti and Sforza (2020) set out to find prominent concerns in cost management with regard to the changing roles of management accountants, the objectives of the businesses they serve and the methods they use in the fulfillment of goals mentioned. A survey was used, and there were nearly 2000 respondents. Among these respondents, $81 \%$ reported that cost management plays a crucial role in the organization's overall strategic goal. Furthermore, it was reported that economic slowdowns tend to generate more demand for cost management since organizations tend to seek more efficient ways of managing costs and financial margins. As such, cost management accountants are now required to be able to generate actionable cost information as well as come up with ways to reduce cost and improve efficiency.

Management accountants are under increased pressure to provide key, opportune, and precise costing information for the purposes of guiding strategic decision making. This is, however, complicated by the fact that various factors cause distortion in cost information. These factors include allocation of overheads, centralized services, and increased product variety (Garg et al., 2013). Even though these existing systems are not providing accurate enough information, organizations still show apprehension in adopting new systems in management accounting that would likely deal with these problems. Transition to new systems is hindered by a preference for the status quo, economic realities, and resource constraints

Douglas (2012) replicated the 2003 study and found that there some significant shifts in some areas. First, there was more focus on cost reduction rather than cost information. Furthermore, there was an increased focus on the human resource constraint, indicating that the management accounting personnel may be lacking in skill or expertise to come up with advanced and disruptive cost information solutions. The study found that traditional costing tools with well-established relationships to financial reporting had increased in popularity; they include Enterprise Resource Planning (ERP) systems, improved budgetary methods, and business intelligence software. There was a significant reduction in the use of target costing, the theory of constants, activity-based 
costing, and value-based management. This is clear evidence that management accountants are apprehensive about moving away from recognized traditional costing approaches pertaining to financial reporting. These approaches include "traditional standard costing, traditional variances, and full absorption costing for inventory valuation and cost of goods sold" (Douglas, 2012). As such, the 2012 study found that $100 \%$ of the respondents recognized that their data was distorted, however, respondents showed an unwillingness to abandon traditional methods and adopt more sophisticated methods of accounting that would address the data distortion problem. Ironically, the demand for greater accuracy in cost information increased from 45\% to 53\% (Douglas, 2012)

Hopper and Bui (2016) found that cost management has become an area of diminishing importance; this is because the current cost management methods are insufficient and only slightly relevant. Furthermore, professionals are lacking in the required skills and expertise to employ advanced methods, and this has shifted focus from cost management to operational planning and forecasting analytics.

\subsection{Traditional Methods of Costing}

Historically companies were using traditional methods of costing. These methods essentially assign overhead costs to products as a function of labor intensity used in the process of production or as a function of the total output of a product produced (Acabbi, Panetti \& Sforza, 2020). These traditional methods were, however, effective because labor made up a notable proportion of the costs involved in producing a product. However, with time, technology has become a major factor of production, and as such, these traditional methods of costing can be misleading. This is because some products can use expensive, low labor-intensive activities during production. Conversely, other products may be labor-intensive with low activity costs. In this case, the traditional costing methods would assign disproportionately high costs to a low-cost product based on the intensity of labor and assign a low-cost overhead to a product that has been costlier to produce. Therefore, any management decision made based on this inaccurate information would be faulty and possibly very costly for an organization. Therefore, as businesses become more cost-efficient, the traditional methods of costing have become unreliable as sources of support for effective decision making (Hopper \& Bui, 2016). This has led to the need for a more comprehensive and reliable methods of allocating overhead costs to products.

\subsection{The Evolution of Management Accounting}

The first age of evolution (before 1950) was primarily focused on cost determination and financial control. Management accounting in this era was concerned with internal affairs, especially optimizing the productivity of businesses. Even though the employment of budgeting and cost accounting procedures was pervasive, the distribution of cost information was slight, and its application in management decision making was almost non-existent. Between 1950 and 1960s management accounting shifted more towards planning and control purposes; this marked the second stage of evolution. Management accounting became more of a managerial activity, and as a result, there was the use of various technologies to facilitate decision making and dependable accounting. However, cost management strategies at this stage concentrated more on internal administration and less on strategic and environmental considerations. Management control systems were, therefore, reactive instead of proactive. The third stage of evolution was marked 
with a shift towards the reduction of wastage of resources during business processes. This is partly credited to the recession of the 70s, and increased competition in the global market in the $80 \mathrm{~s}$ (Cooper \& Kaplan, 1988). Furthermore, the development of computers increased the amount of data that managers could openly access and therefore, the design, maintenance, and interpretation of information systems became a critical part of effective management. The fourth stage was marked with the generation and creation of value through the effective use of resources. This was a result of unprecedented development in technology, which led to phenomenon such as ecommerce in the '90s, which further increased and emphasized the challenge posed by increased competitiveness in the global arena.

It can be therefore noted that management accounting ha progressively moved towards resource management through waste management and value creation. The efficient use of assets, including information to create value within organizations, has over time become a critical part of the management process. There has, therefore been a movement towards sophisticated accounting methods to deal with challenges that arise due to various developments in technology. There is now the need for a business management accounting system to produce information necessary for planning, controlling, and decision making all with the objective of creating or enhancing the value of products or services (Baldvinsdottir et al., 2010).

\subsubsection{Change resistance}

Organizational routines, especially regarding institutionalized practices, are very slow to change, and when change comes, there is often resistance. There is often an insistence on the stability of management account practices, especially when operating in an unstable environment so as to bring about consistency in decision making (Kastberg \& Siverbo, 2016). Furthermore, some employees are opposed to change due to the fact that they fear that they will lose their position within an organization. Employees who have worked with an organization for some time have a very good grasp of the existing system; therefore, by implementing a new system, these employees are brought back to square one just like everyone else. They, therefore, worry that the implementation of new accounting systems may affect their productivity or limit their chance of progress within the corporation or even lead to their firing. Therefore, despite economic efficiency and cost control capability, a new accounting system may offer. It may fail to be effective due to a lack of cooperation from among employees. It is, therefore, necessary to present changes gradually while making sure that communication channels are open so that employees can understand why changes are necessary. Furthermore, when adopting a new accounting system, it is best to find systems that align with the existing system to limit the adjustment time as well as possible resistance from employees.

\subsubsection{Implications of traditional methods on decision making}

Managers make very critical decisions regarding pricing, product mix, and process information using inaccurate cost information. What's worse is the fact that managers often lack alternative sources of information about product costs and are therefore only able to detect the problems after the competitiveness and profitability of businesses have greatly reduced. This problem affects larger organizations with a diverse range of products significantly more. This is because it is harder 
for these organizations to trace the cost of the most vital production factors, such as labor and materials. With the expansion of product offerings and distribution channels, direct costs related to labor now make a small proportion of total costs. Expenses covering operational support, marketing, distribution, engineering, among other overhead allocations have gone through the roof. Use of simplistic methods in coming up with costing information is no longer justifiable and is especially dangerous for a company operating in an aggressive business environment. This is because accurate cost information has become essential to competitive success (Kokubu \& Kitada, 2015). Managers possess the knowledge that their accounting systems often bring about distortions; they, therefore, make various adjustment to compensate for these distortions. However, only very few can predict the magnitude and impact these adjustments bring about.

\subsection{Misallocation and Cost Management}

The choice of what to produce is often made by the executive branch of an organization and a common problem identified in the decision-making process is that management may understate the profitability of high volume products and overstate the profitability of specialty products. In order for firms to become low-cost producers, firms are required to examine their internal activities and ensure that they are following a combination of activities that does create value. A business is only profitable if the value chain produces products or services that can be bought for more than the product's creation cost and delivery costs to the market (Drucker, 2012). A business must, therefore, develop methods through which it can increase the value of a product or service by performing various value-adding procedures in the value chain. This implies that, when a firm allocates finances to the wrong product, it will most likely be bleeding money and making losses.

Increased product lines and marketing channels have brought about the problem of misallocation of overhead costs; businesses, therefore, have a hard time distinguishing between which products are profitable and which ones are bringing about losses. Furthermore, due to misallocation, businesses may end up charging the wrong prices to their customers, and as such, they may be wasting resources on products they mistakenly believe are profitable. These financial misallocations have therefore increased pressure for management accountants to come up with more accurate information regarding the costing information of various products. This has led to the demand for the use of more sophisticated techniques in accounting systems. One popular method is Activity-Based Cost Management (ABCM). This method has been applied as both a management tool and a corporate philosophy. This is because ABCM seeks to identify deficiencies and potential wastage in product costs, management practices, and management processes. This method has extended beyond the finance and accounting department and has essentially become part of the corporate strategy and culture (Restuccia \& Rogerson, 2017). Through the use of this technique, managers have been able to develop and maintain a cost leadership strategy, especially in highly competitive environments.

Financial misallocation has, therefore led to a situation where accountants have become integrated further into the corporate framework of organizations (Restuccia \& Rogerson, 2017). This is because sophisticated accounting techniques such as ABCM are linked to continuous improvement and planning tools such as total quality management, value engineering programs, business process analysis, and statistical quality control. Activities performed throughout the business 
process, therefore, become critical elements in determining the value of the process. Accounting procedures have, therefore evolved to the point that they are being used to determine competitive competencies, work process value and product and consumer profitability. This is based on the understanding that business activities use up resources and resources cost money (Cooper, 2017). Therefore, by tracing all the activities, it is possible to determine the true cost of a product or a service. Through these processes, it is, therefore, possible to provide management with information (pertaining to cost and operations) that enables them to make strategic decisions that suit their competitive position in the market.

Accurate cost data is necessary for an organization to be able to become a low-cost supplier of a product or a service and hence acquire a competitive advantage. It is, therefore, necessary for management to be aware of what activities consume most resources and consequently incur the most costs. This eventually ensures that management is able to allocate its financial resources to the most cost-effective and profitable products by eliminating non-value adding costs, finding problem areas and eliminating them hence introducing efficiency and effectiveness in the production process (Cooper, 2017). This results in a streamlined value-adding process which improves or optimizes yield. Through ABCM, for instance, it is possible to eliminate non-value adding processes; these are processes which do not contribute to customer satisfaction and hence can be eliminated without interfering with the integrity and quality of a product or service. Misallocation, therefore, calls for the culture of a company to change into a system that prioritizes customers and strive to perform only those activities that add value to a product.

The entire management accounting process (planning, controlling, decision-making and communicating) has evolved from the basic role of cost determination and financial control to the more sophisticated function of creating or enhancing value through improved allocation of resources. The new accounting techniques being employed are in support of new technologies and in response to new management systems such as total quality management, just in time production systems and the pursuit of a competitive edge in the global markets.

Hesterly and Barney (2010) argue that in American industries, there is a lot of focus on qualityquality products, quality systems, and quality improvements. Financial misallocation often results from management focusing solely on quality without making other considerations. Financial difficulties that often result from such miscalculations have prompted leaders to seek the input of management accountant since it is not impossible to take on all quality improvement projects due to the constraint of limited resources. Advanced management tools and techniques such as ABC/M play a major role in cost justification and prioritization of various quality improvement projects. This is because it is possible to determine the value each project will have and hence decide which one to pursue first. Without this information firm often find themselves pursuing low-value quality improvement projects at great risk and little gain.

Hesterly and Barney (2010) found that sophisticated managerial accounting methods and tools are best applied in organizations with the following characteristics:

- Organizations operating in highly uncertain environments

- Organizations operating in markets where customers have a lot of power 
Stratford Peer Reviewed Journals and Book Publishing Journal of Finance and Accounting

Volume 5||Issue 4||Page 1 -11 ||October||2021|

Email: info@stratfordjournals.org ISSN: 2616-4965

- Organizations with a decentralized structure

- Organizations which are relatively large in size

- Organizations employing Total Quality Management (TQM), Alternative Minimum Tax (AMT) and Just in Time (JIT) inventory

\subsection{Financial Misallocation, Change in Strategy and Impact on Cost Management}

Financial misallocation can also bring about a change in management, which can bring about different strategies to help the business recover and gain back its market share. Misallocations often call for the re-evaluation of existing strategies and the pursuit of more effective and efficient methods in production and marketing. Enterprise Resource Management (ERP) systems is one strategy through which organizations can be able to increase efficiency and productivity by streamlining operations (Restuccia \& Rogerson, 2013). Through ERP's business processes are fully integrated, a system that allows for access to real-time information about a business. Implementation of these systems has various implications for accountants and accounting systems since they call for more teamwork, cross-functionality, and information sharing. It has been argued that by the implementation of this system, the responsibilities of management accountants may be on the decline due to the fact that manager can be able to access to information they need to control costs and operations online. With access to comprehensive and detailed information needed for decision support and control, managers no longer have to wait for periodic reports from cost management personnel. Some, however, argue that ERPs will only change the job description of the management accountants as they will become internal advisors and consultants to the managers

An example of how financial misallocation can affect cost management is exemplified by the cause of Building Materials Inc. (BM Inc.). In 1986 following a recapitalization resulting from a hostile takeover, the company owed $\$ 1$ billion in negative shareholder equity with a long term debt $\$ 1.65$ billion and had employed a cost reduction strategy that basically crippled all expenditure. This eventually led to a decline in sales. However, after a change in leadership, the new CEO pursued a growth strategy, in the years to come, the company expanded rapidly through a combination of internal reorganization and acquisitions and by the year 1995, the sales of the company had expanded from $\$ 2.8$ billion to $\$ 3.6$ billion. In order to sustain this level of growth, the company needed to develop a corporate information system and an information-oriented culture. This was due to the fact that many of the acquired companies had different information systems. Maintaining these different systems was both expensive and difficult. Costs of maintaining these systems were averaging at $\$ 35$ million a year, and hence the company considered installing SAP (an ERP system) which was at the time a powerful but very complex system. SAP offered a corporate information system that would enable the company to operate homogeneously throughout the world. This system would integrate all the company's business information, including its financial information (Spraakman et al., 2017).

Albeit some challenges related to lack of customization of the SAP software, the implementation of SAP was successful; in fact, the system stimulated the integration of finance, accounting and other business processes. Accountants would start seeing themselves as processes rather than functions. Focusing on processes can, in fact, led to lower costs, short cycle times, and increased customer satisfaction. Through the implementation of SAP, historical information provided by 
accountants became less relevant since managers had access to real information. Budgets shifted from being static and became more dynamic and flexible. This is because the initial framework could be revised and modified as the year progressed enabled by the process of ongoing forecasting that was brought about by access to real-time information. The business, therefore, became more forward-looking (Spraakman et al., 2017).

Characteristics of management account information were not affected significantly; however, there was a change in the job description of management accountants within the organization. First of all, most of the routine jobs by cost clerks and other accounting personnel were no longer necessary since they were taken over by SAP or centralized in a shared services centers. This potentially meant that these accountants would lose their jobs or lose some of their skills which were no longer needed due to lack of practice. The role of accountants, therefore, became more analytical. This is because they were responsible for systems, not actual reports since managers were able to access reports on their own. Cost management essentially became a managerial activity and was no longer an accounting activity (Spraakmanat et al., 2017). This is because the information needed for cost management became readily available to managers through the SAP system. Management accountants would play the role of consultants since they would assist managers in strategizing and making operational decisions

In these cases, cross-functional teams also become the norm, as such decision making involves interactions between different managers from different backgrounds and with different capabilities (Baldvinsdottir, Mitchell \& Nørreklit, 2010). Management accountants, therefore, end up taking up a bigger role within the organization since they are required to link cost and financial information to the strategic approach a business adopts.

The implementation of an ERP system at BM Inc. had the following implications for cost management:

- Routine jobs were eliminated; routine jobs by the accounting department could be computerized

- Managers were armed with accounting information and as a result, played a more significant role in cost management

- There was reliance on more forward-looking information instead of historical information

- There was an expansion in the role of management accountants since they were now more involved in strategy and decision making (Spraakman at al., 2017)

\subsection{Conclusion}

Due to competitiveness in the global marker, firms must be strategic in order to survive. Therefore, setbacks arising from financial misallocation need to addressed by implementing systems that give the firm a competitive advantage and protects the firm position within the industry it operates. There is a need to transition from traditional methods of accounting to modern methods to ensure that financial misallocations are a thing of the past. By doing so, the firm will move from being reactive to being proactive as well as have access to accurate information that will facilitate strategizing and decision making. Financial misallocations have, therefore led to the demand for 
more sophisticated accounting techniques and methods. This has, in turn, made cost management a managerial process instead of an accounting activity. Furthermore, these systems have changed the role of the management accountant from reporting to a more involved stakeholder in strategy and decision making. This has, in turn, led to the loss of various skills and competencies among accountants since some of their functions are now computerized. There is, however, a lot of apprehension in adopting these new sophisticated techniques of accounting, a subject that should perhaps be investigated further.

\section{References}

Acabbi, E. M., Panetti, E., \& Sforza, A. (2020). The financial channels of labor rigidities: Evidence from Portugal.

Baldvinsdottir, G., Mitchell, F., \& Nørreklit, H. (2010). Issues in the relationship between theory and practice in management accounting. Management Accounting Research, 21(2), 7982. https://doi.org/10.1016/j.mar.2010.02.006

Boeri, T., Ichino, A., Moretti, E., \& Posch, J. (2019). Wage equalization and regional misallocation: evidence from Italian and German Provinces. Journal of the European Economic Association. https://doi.org/10.3386/w25612

Cooper, R. (2017). Target costing and value engineering. Routledge. https://doi.org/10.1201/9780203737378

Cooper, R., \& Kaplan, R. S. (1988). Measure costs right: make the right decisions. Harvard business review, 66(5), 96-103.

Douglas Clinton CMA, C. P. A. (2012). Roles and practices in Management accounting: 20032012. Strategic Finance, 94(5), 37.

Drucker, P. (2012). Managing for results. Routledge. https://doi.org/10.4324/9780080575315

Fullerton, R. R., Kennedy, F. A., \& Widener, S. K. (2013). Management accounting and control practices in a lean manufacturing environment. Accounting, Organizations and Society, 38(1), 50-71. https://doi.org/10.1016/j.aos.2012.10.001

Garg, A., Ghosh, D., Hudick, J., \& Nowacki, C. (2013). Roles and practices in management accounting today. Strategic Finance, 85(1), 30.

Hao, Y., Gai, Z., \& Wu, H. (2020). How do resource misallocation and government corruption affect green total factor energy efficiency? Evidence from China. Energy Policy, 143, 111562. https://doi.org/10.1016/j.enpol.2020.111562

Hesterly, W., \& Barney, J. (2010). Strategic management and competitive advantage. Upper Saddle River, NJ.

Hopper, T., \& Bui, B. (2016). Has management accounting research been critical?. Management Accounting Research, 31, 10-30. https://doi.org/10.1016/j.mar.2015.08.001 
Kastberg, G., \& Siverbo, S. (2016). The role of management accounting and control in making professional organizations horizontal. Accounting, Auditing \& Accountability Journal, 29(3), 428-451. https://doi.org/10.1108/AAAJ-03-2014-1632

Kokubu, K., \& Kitada, H. (2015). Material flow cost accounting and existing management perspectives. Journal of Cleaner Production, 108, 1279-1288. https://doi.org/10.1016/j.jclepro.2014.08.037

Lenzu, S., \& Manaresi, F. (2019). Sources and implications of resource misallocation: new evidence from firm-level marginal products and user costs. Bank of Italy Occasional Paper, (485). https://doi.org/10.2139/ssrn.3432978

Marconi, D., \& Upper, C. (2017). Capital misallocation and financial development: a sector-level analysis. Bank of Italy Temi di Discussione (Working Paper) No, 1143. https://doi.org/10.2139/ssrn.3066694

Nguyen, P. T., \& Nguyen, M. K. (2020). Misallocation and reallocation of resources in Vietnamese manufacturing firms. Journal of Economic Studies. https://doi.org/10.1108/JES-04-20190168

Restuccia, D., \& Rogerson, R. (2013). Misallocation and productivity. https://doi.org/10.1016/j.red.2012.11.003

Restuccia, D., \& Rogerson, R. (2017). The causes and costs of misallocation. Journal of Economic Perspectives, 31(3), 151-74. https://doi.org/10.1257/jep.31.3.151

Spraakman, G., O'Grady, W., Askarany, D., \& Akroyd, C. (2018). ERP systems and management accounting. Journal of Accounting \& Organizational Change. https://doi.org/10.1108/JAOC-06-2016-0038

Wang, Y., Lei, X., Yang, F., \& Zhao, N. (2021). Financial friction, resource misallocation and total factor productivity: theory and evidence from China. Journal of Applied Economics, 24(1), 393-408. https://doi.org/10.1080/15140326.2021.1936836 